\title{
UPAYA PENGEMBANGAN KEMANDIRIAN ANAK USIA DINI DALAM PEMBELAJARAN KELOMPOK A RA RAIHAN PERSIS 27 KECAMATAN CIHIDEUNG
}

\author{
(Penelitian Kualitatif Deskriptif pada Guru Kelompok A di RA Raihan Persis 27 Kecamatan \\ Cihideung Kota Tasikmalaya)
}

\author{
Rosmaya $^{1}$, Edi Hendri Mulyana ${ }^{2,}$ Tri Lestari $^{3}$ \\ ${ }^{1}$ Program Studi PGPAUD UPI Kampus Tasikmalaya \\ ${ }^{2}$ Program Studi PGPAUD UPI Kampus Tasikmalaya \\ ${ }^{3}$ Program Studi PGPAUD UPI Kampus Tasikmalaya
}

Email: r_maya47@yahoo.com

(Received: Mei 2019; Accepted: Mei 2019; Published: Juni 2019)

\begin{abstract}
Child independence is a capital of creativity, progress and survival. The non-indepedence of the child forms a personality that depends on other and will hamper the progress of the child, therefore independence must be instilled from an early age to the child in order to grow into an independent human being. Efforts to develop independence in schools are done by teachers who interact intensely with children. These development efforts can be applied in the learning process. The learning process is divided into several activities, namely the welcoming of the child's arrival, opening, core activities, covering and picking up the children. The research is conducted because it wants to reveal how the teacher developed in the learning process. This research uses qualitative approach with descriptive method. The research was conducted at RA Raihan Persis 27, District Cihideung, Tasikmalaya City. Participants of this research are teacher of group A RA Raihan Persis 27. The collection was done by observation, interview and document study. The research findings show that the way the teacher develops the child's independence is done in the form of a program that is made into the rules of school rules and class rules. The teacher's program is implemented through statements and action. In addition, teachers apply the system of habituation to children to develop independence of children As for the aspects of independence that is dominated by teachers developed in RA Raihan Persis 27 is confident, discipline, emotional control and responsibility.
\end{abstract}

Keywords: independence, teacher, children

\begin{abstract}
Abstrak
Kemandirian anak merupakan modal kreativitas, kemajuan dan daya keberlangsungan hidup (survival). Ketidakmandirian anak membentuk kepribadian yang bergantung kepada orang lain dan akan menghambat kemajuan anak, oleh karena itu kemandirian harus ditanamkan sejak dini kepada anak supaya dapat tumbuh menjadi manusia yang mandiri. Upaya pengembangan kemandirian di sekolah dilakukan oleh guru yang berinteraksi secara intens dengan anak. Upaya pengembangan tersebut bisa diterapkan dalam proses pembelajaran. Proses pembelajaran dibagi menjadi beberapa kegiatan, yaitu kegiatan penyambutan kedatangan anak, pembukaan, kegiatan inti, penutup dan penjemputan anak. Penelitian ini dilaksanakan karena peniliti akan mengungkapkan bagaimana cara guru mengembangkan kemandirian anak serta aspek kemandirian apa saja yang dikembangkan dalam proses pembelajaran. Penelitian ini menggunakan pendekatan kualitatif dengan metode deskriptif. Penellitia ini dilakukan di RA Raihan Persisn 27, Kecamatan Cihideung Kota Tasikmalaya. Partisipan pada penelitian ini adalah guru kelompok A RA Raihan 27. Pengumpulan data dilakukan dengan teknik observasi, wawancara dan studi dokumen. Hasil dari temuan penelitian menunjukkan bahwa cara guru mengembangkan kemandirian anak dilakukan dalam bentuk program yang dibuat menjadi aturan yaitu aturan sekolah dan aturan kelas. Program tersebut guru laksanakan melalui pernyataan dan tindakan. Selain itu juga guru menerapkan sistem pembiasaan kepada anak untuk mengembangkan kemandirian anak. Adapun aspekaspek kemandirian yang mendominasi dikembangkan oleh guru di RA Raihan Persis 27 adalah percaya diri, disiplin, mengendalikan emosi dan tanggungjawab.
\end{abstract}

Kata kunci: kemandirian, guru, anak 


\section{PENDAHULUAN}

Anak usia dini adalah anak yang berada pada usia 0-8 tahun, dimana pada masa ini anak sedang berada pada tahap perkembangan yang sangat pesat karena pada masa ini anak akan mengalami masa golden age atau masa keemasan. Hal ini sependapat dengan Sujiono (2013, hlm. 6) yang menyatakan bahwa "anak usia dini adalah sosok individu yang sedang menjalani suatu proses perkembangan dengan pesat dan fundamental bagi kehidupan selanjutnya. Anak usia dini berada pada rentang usia 0-8 tahun". Anak yang sedang berada pada masa golden age akan mudah menerima rangsangan yang diberikan oleh lingkungan disekitarnya, hal ini sejalan dengan pendapat Montessori (dalam Sujiono 2013, hlm.202) yang menyatakan "usia keemasan merupakan usia dimana anak mulai peka untuk menerima berbagai upaya pendidikan dari lingkungannya baik disengaja maupun tidak disengaja".

Pada kehidupan sehari-hari banyak hal yang harus dilakukan anak untuk dapat memenuhi kebutuhannya, misalnya makan, memakai baju, mandi, bermain, dan lain sebagainya. Jika anak yang mandiri, maka dia akan berusaha melakukan semua kegiatan tersebut sendiri atau dengan sedikit bantuan. Banyak orangtua yang mengidam-idamkan anaknya bisa tumbuh menjadi anak yang mandiri, tetapi pada kenyataannya tidak sedikit orangtua atau orang dewasa yang salah mengekspresikan cinta kepada anak. Tidak sedikit orangtua terlalu berlebihan ketika memberikan pelayanan dan pengasuhan kepada anak. Tidak jarang orangtua atau pendidik merasa percaya akan kemampuan anak untuk melakukan sesuatu hal dengan sendiri, sehingga mereka tidak diberi kesempatan untuk melakukan hal tersebut dengan mandiri. Padahal jika anak sudah mampu melakukan semua kebutuhannya sendiri, anak dan orangtua akan sama-sama beruntung. Anak yang mandiri tidak akan bergantung pada oranglain dan orangtua tidak akan terlalu direpotkan ketika harus mengurus anaknya, terlebih orangua yang sibuk dengan pekerjaannya. Dalam hal ini perlu adanya kerjasama antara orangtua dan pihak-pihak terkait untuk dapat membentuk anak menjadi mandiri secara bersama-sama.

Menurut Bukhari (2014, hlm. 6) kemandirian anak merupakan modal dari kreativitas, kemajuan dan daya tahan keberlangsungan hidup (survival). Sementara ketidakmandirian membentuk kebergantungan pada oranglain dan menghambat kemajuan.. Jika kemandirian anak tidak dilatih dari kecil, maka anak akan tumbuh menjadi seorang pengikut (followers) saja, dia akan merasa takut ketika berpisah dengan orangtuanya, tidak memiliki keberanian untuk mengambil keputusan, dan lain sebagainya.

Kemandirian menurut Desmita (dalam Marti 2015, hlm. 9 ) berasal dari kata dasar "diri" yang mendapat imbuhan "ke" dan "an" yang membentuk suatu kata keadaan atau benda. Diri merupakan inti dari kemandirian. Konsep lain yang sering digunakan dengan kemandirian adalah autonomy. Menurut Chaplin (dalam Desminta, 2012, hlm. 185) mengungkapkan bahwa otonomi adalah kebebasan individu manusia untuk memilih, untuk memerintah, menguasai dan menentukan dirinya sendiri. Sedangkan menurut Steinberg (dalam Putra dan Jannah, 2013, hlm.2) menyatakan bahwa kata mandiri berasal dari dua istilah yang pengertiannya sering disejajarkan silih berganti, yaitu "autonomy" dan "indenpence". Keduanya memiliki arti yang tidak jauh berbeda. Indenpendence dalam arti kebebasan secara umum mengandung makna kemampuan individu untuk melakukan sendiri aktivitas hidup tanpa menggantungkan kepada orang lain. Berdasarkan penjelasan tersebut dapat disimpulkan bahwa kemandirian atau otonomi adalah kemampuan untuk mengendalikan dan mengatur pikiran, perasaan, dan tindakan sendiri secara bebas serta berusaha sendiri untuk mengatasi perasaan-perasaan malu dan keragu-raguan.

Erikson (dalam Desmita 2012, hlm.185) menyatakan bahwa keamandirian adalah usaha untuk melepaskan diri dari orangtua dengan maksud untuk menemukan dirirnya melalui proses mencari identitas ego. Hal ini dimaksudka untuk mengarahkan 
perkembangan individualitas yang mantap dan berdiri sendiri. Yatim (dalam Rantina 2015, hal 182) mengungkapkan bahwa kemandirian merupakan kemampuan hidup yang utama dan salah satu kebutuhan sejak awal usianya.

Membentuk sifat kemandirian dalam diri anak tidaklah mudah. Sifat kemandirian dibentuk melalui proses yang lama dan harus dilalui secara bertahap. Kemandirian harus dilalui secara bertahap karena kematangan seorang anak harus dilalui sesuai dengan usianya. Ketika anak lahir, segala macam pemenuhan kebutuhannya bergantung pada orang lain. Kebutuhan untuk minum, makan, berpakaian, kesehatan, kasih sayang, rasa aman, kebutuhan perangsangan mental, serta kebutuhan sosial dan emosional.

Menurut Lina (2015) perilaku yang diharapkan muncul dari aspek sosial-emosional dari anak usia dini, yaitu perilaku-perilaku yang baik dan positif seperti kedisiplinan, kemandirian, tanggungjawab, percaya diri, jujur, adil, setia kawan, sifat kasih sayang sesama serta toleransi yang tinggi. Kemudian dalam STPPA (standar Tingkat Pencapaian Perkembangan Anak) salah satu sikap yang harus muncul pada anak usia 4-5 tahun adalah menunjukkan sikap mandiri dalam memilih kegiatan, mengendalikan perasaan, menunjukkan rasa percaya diri, memahami peraturan dan disiplin, memiliki sikap gigih (tidak mudah menyerah), dan bangga terhadap hasil karya sendiri.

Dari beberapa pendapat tersebut dapat disimpulkan bahwa sikap atau perilaku kemandirian anak harus ditanamkan sejak dini. Anak yang mandiri sudah pasti memiliki perilaku disiplin, tanggungjawab, percaya diri, mampu mengendalikan emosinya, pandai bergaul dengan temannya, dan lain sebagainya. Hal ini sesuai dengan yang diungkapkan Brewer (dalam Lina 2013, hlm.3) bahwa "indikator kemandirian anak diantaranya kemampuan fisik, percaya diri, bertanggungjawab, disiplin, pandai bergaul, mau berbagi dan mampu mengendalikan emosi"
Menurut Havighurst (dala Komala 2015, hlm. 37) membedakan bentuk kemandirian menjadi empat, yaitu kemandirian emosi, kemandirian ekonomi, kemandirian intelekual dan kemandirian sosial. Anak yang mandiri sejak dini akan terbawa sampai nanti dewasa. Kemandirian merupakan satu karakter yang memiliki manfaat samgat besar, karena anak yang mandiri akan meng-cover berbagai karakter laimmya, seperti karakter tanggung jawab, disiplin, percaya diri, dan lain sebagainya. Asrosi (dalam Rantina 2015, hlm. 185) menyatakan bahwa kemadirian berfungsi untuk membantu mencapai tujuan hidupnya, prestasi, kesuksesan serta memperoleh pengahargaan. Selain itu kemandirian juga memiliki beberapa fungsi yang dikemukakan oleh Aryanti (dalam Marti 2015), yaitu mengarahkan diri sendiri dan dapat mengambil keputusan, seperti dapat mengatur kegiatan sendiri, memilih permainan sendiri, memilih baju sendiri, dan lain sebagainya; Sosial emosional, seperti dapat berempati kepada orang lain, mau berbagi dengan orang lain, mau berteman dengan teman, dan lain sebagainya; Menemukan identitas diri, seperti anak bisa percaya diri dan terampil sehingga anak tidak akan ragu dalam mengerjakan tugas atau aktivitasnya; Pengelolaan diri, seperti ketika anak sedang berlari kemudia didepannya ada lubang kemudian anak akan berhenti secara spontan karena anak memiliki kemampuan untuk menglola dirinya, atau anak tidak mudah menangis saat ditinggal oleh orangtuanya; dan moral, seperti anak mampu bertanggungjawab atas apa yang telah dia lakukan.

Pendidikan bisa menjadi alternatif untuk melatih kemandirian anak usia dini. Pendidikan bisa dilakukan di rumah, di sekolah atau dilingkungan bermain anak. Pendidikan dirumah dan dilingkungan alami tentunya akan berbeda dengan pendidikan yang diberikan di sekolah, karena pendidikan yang diberikan dirumah dan dilingkungan biasanya berjalan alami, spontan dan tanpa perencanaan, sekalipun direncakan tidak sama dengan hasil yang diberikan di sekolah. Berbeda dengan halnya pendidikan yang diberikan disekolah, biasanya pendidikan yang diberikan disekolah 
lebih efektif karena tempat dan semua hal yang diperlukan untuk menunjang keberlangsungan pembelajaran sudah dipersiapkan sedemikian rupa untuk mencapai tujuan yang diinginkan.

Pendidikan merupakan jalan untuk dapat mengembangkan semua potensi yang ada pada diri anak, seperti yang telah dijelaskan oleh Undang-Undang Republik Indonesia Nomor 20 Tahun 2003 tentang Sistem Pendidikan Nasional pada pasal 1 , ayat 1 yang berbunyi :

Pendidikan adalah usaha sadar dan terencana untuk mewujudkan suasana belajar dan proses pembelajaran agar peserta didik secara aktif mengembangkan potensi dirinya untuk memiliki kekuatan spiritual keagamaan, pengendalian diri, kepribadian, kecerdasan, akhlak mulia serta keterampilan yang diperluan untuk dirinya, masyarakat, bangsa dan Negara.

Dalam Pendidikan Anak Usia Dini ada beberapa aspek yang harus dikembangkan didalamnya, seperti yang telah diatur dalam Peraturan Menteri Pendidikan dan Kebudayaan Republik Indonesia Nomor 137 Tahun 2014 tentang Standar Isi Tentang Tingkat Pencapaian Perkembangan Anak, yaitu (1)aspek nilai agama dan moral, (2)aspek fisikmotorik, (3)aspek kognitif, (4)aspek bahasa, (5)sosial-emosional dan (6)aspek seni. Sesuai dengan peraturan tersebut maka setiap PAUD wajib melaksanakan pendidikan yang dapat mengembangkan keenam aspek tersebut.

Sekolah sebagai pendidikan formal harus mampu mendidik dan memberikan pelayan terbaik kepada semua peserta didiknya. Orangtua memasukan anaknya ke sekolah yang mereka pilih berarti mereka sudah mempercayai sekolah tersebut untuk dapat mendidik anak-anaknya, maka dari itu selama disekolah pendidik mempunyai peran yang sangat besar disana dan tentunya dengan segudang tanggungjawab besar pula untuk dapat mendidik anak sesuai dengan apa yang diharapkan orangtua. Upaya yang dilakukan guru saat mendidik anak adalah saat proses pembelajaran. Aliran behavioristik menyebutkan bahwa pembelajaran adalah usaha guru membentuk tingkah laku yang diinginkan dengan menyediakan lingkungan atau stimulus (Hamdani , 2011. Hlm. 23).
Pernyataan tersebut menjelaskan bahwa segala sesuatu yang disediakan dan dilakukan guru kepada anak sebagai bentuk usaha untuk membentuk perilaku anak ke arah yang lebih baik. Tugas guru adalah menyediakan lingkungan yang memungkinkan anak memperoleh pengalaman. Dalam hal ini terkait dengan bagaimana anak berkembang secara sosial, emosional dan intelektual. Sedangkan aliran kognitif mendefinisikan pembelajaran sebagai cara guru memberikan kesempatan kepada siswa untuk berpikir agar mengenal dan memahami sesuatu yang sedang dipelajari (Darsono dalam Hamdani , 2011. Hlm. 23). Anak bukan pembelajar pasif yang hanya menerima pengetahuan dari orang dewasa. Namun sebaliknya anak pembelajar aktif yang mampu membangun pengetahuannya sendiri melalui pemahaman terhadap dunia di sekeliling mereka.

Salah satu strategi dalam pembelajaran di PAUD yaitu menggunakan strategi pembelajaran sentra dan waktu lingkaran. Strategi Pembelajaran dengan Pendekatan Sentra dan Waktu Lingkaran. Sentra dapat diartikan sebagai suatu wadah yang disiapkan oleh guru untuk kegiatan bermain anak, dimana dalam kegiatan tersebut guru dapat mengalirkan materi pembelajaran yang sebelumnya telah direncanakan dan disusun dlaam bentuk lesson-plan, (Latif, 2014. Hlm.104). kegiatan yang disiapkan oleh guru saling berkaitan dan mendukung satu sama lainnya sehingga dapat mencapai tujuan pembelajaran secara optimal. Semua sentra memiliki tujuan yang sama pada setiap harinya. Satu kelompok anak dapat menghabiskan waktu bermain mereka dalam satu sentra. Pada kegiatan-kegiatan di sentra dilaksanakan dengan menggunakan tema secara serempak atau sama untuk setiap sentra dan dijalankan dalam waktu tertentu. Kegiatan sentra dilakukan dengan memerhatikan tahapan-tahapan kegiatan yang dimulai dari pagi hari pada saat kegiatan penyambutak kedatangan anak di sekolah sampai akhir kegiatan yang telah disiapkan guruu hingga akhirnya anak kembali pada keluarganya masing-masing. Selain itu, di sentra anak-anak akan belajar tentang mandiri dan disiplin 
melalui langkah-langkah kegiatan yang harus dilakukan oleh anak dan aturan yang telah diberikan kepada anak selama berada dalam sentra. Adapun beberapa sentra yang dikembangkan oleh penemunya di Indonesia, yaitu sentra persiapan, sentra balok, sentra main peran besar, sentra main peran kecil, sentra bahan alam, sentra seni dan sentra imtaq.

Dari hasil studi pendahuluan di RA Raihan Persis 27 Kecamatan Cihideung Kota Tasikmalaya penulis melihat kemandirian anak disana sangat baik. Mereka disana terlihat sangat mandiri selama proses pembelajaran disekolah, yaitu mulai dari kegiatan penyambutan kedatangan anak, pembukaan, kegiatan inti, penutup dan penjemputan anak. Contoh dalam kegiatan penyambutan kedatangan anak, yaitu anak membawa tas sendiri dari mulai masuk gerbang sekolah sampai ke dalam kelas setelah itu anak membuka sepatunya sendiri. Contoh dalam kegiatan pembukaan, yaitu anak dibiarkan untuk mengekspresikan dirinya melalui jurnal pagi (menggambar) tanpa dibantu guru. Selanjutnya contoh dari kegiatan inti, yaitu anak dibebaskan untuk memilih raga main, dan contoh kegiatan penutup anak diberi kesempatan untuk makan dan pada kegiatan tersebut anak mampu menyeesaikan tahapantahapan makan. Anak makan sendiri dari mulai cuci tangan, mengambil makan sendiri sampai membereskan alat makannya sendiri. Contoh terakhir adalah contoh dari kegiatan penjemputan anak, yaitu anak mampu memakai alas kakinya sendiri.

Anak tidak bisa mandiri tanpa pemberian treatment, anak yang mandiri tidak terlepas dari sosok yang mendidiknya. Peran pendidik sangatlah besar dalam proses pembelajaran anak. Pendidik adalah seseorang yang merencanakan, melaksanakan dan mengevaluasi pendidikan yang diterapkan. Pendidik yang dimaksud disini adalah guru. Guru merupakan sosok yang mengatur segala sesuatu untuk terlakasanya proses pembalajaran yang maksimal dan menghasilkan suatu perubahan yang baik terhadap peserta didiknya. RA Raihan merupakan sekolah yang memiliki persiapan yang cukup matang dalam hal perencanaan dan pelaksanaan kemandirian anak. Mereka memiliki strategi yang baik dalam mengembangkan kemandirian anak.

Dalam mengembangkan kemandirian anak, RA Raihan memiliki kurikulum dan SOP yang memang disiapkan untuk mengembangkan kemandirian anak. Selain itu untuk mengembangkan kemandirian anak, RA Raihan memiliki program unggulan yang membedakan dengan PAUD lainnya dan program ini merupakan salah satu cara untuk memantapkan anak menjadi anak yang mandiri sesuai dengan tujuan sekolah. Program tersebut, yaitu snack time, makan siang dan shalat dzuhur. Saat snack time dan makan siang guru tidak hanya sekedar memberikan makan kepada anak dan anak tidak sekedar mengisi perut kosong saja, tetapi guru menerapkan pendidikan makan yang sudah disiapkan dalam kurikuum makan dari mulai anak mencuci tangan sendiri, mengambil alat makan sendiri, mengambil makanan sendiri sampai menyimpan alat makan dan mencuci alat makan sendiri. Program tersebut sangat membantu anak untuk mengembangkan kemandiriannya secara optimal, melalui pembiasaan yang diterapkan diharapkan anak mampu menjadi anak yang mandiri tidak hanya disekolah tetapi dimana pun anak berada anak mampu memenuhi kebutuhannya sendiri.

Berdasarkan hasil studi pendahuluan tersebut, penulis ingin mengungkap secara detail untuk mengetahui upaya guru dalam mengembangkan kemandirian anak di RA Raihan dalam proses pembelajaran disekolah sehingga mereka dapat melahirkan anak-anak yang mandiri. Maka dari itu penulis mengambil judul penelitian "Analisis Upaya Pengembangan Kemandirian Anak Usia Dini Dalam Proses Pembelajaran Kelompok A RA Raihan Persis 27 Kecamatan Cihideung". Alasan penulis memilih subjek penelitiannya kelompok A, karena di RA kelas A merupakan kelas paling rendah dan usia yang paling dini disana, sehingga kemandirian sangat penting ditamankan sejak usia dini sebagai pondasi, maka dari itu penulis ingin meneliti cara guru mengembangkan tentang kemandirian anak sejak usia sedini mungkin. 


\section{METODE PENELITIAN}

Pendekatan penelitian yang digunakan adalah kualitatif dengan metode deskriptif. Pendekatan kualitatif adalah penelitian yang ditujukan untuk melihat dan memahami masalah-masalah sosial seperti manusia, lembaga atau berdasarkan fakta yang tampil secara apa adanya atau dengan setting alamiah. Sedangkan Metode yang digunakan dalam penelitian ini adalah metode deskriptif yaitu penelitian yang berusaha melaporkan suatu kejadian dengan cara mendeskripsikannya baik itu mendeskripsikan suatu kejadian, peristiwa, fenomena atau yang lainnya yang sedang terjadi saat ini. Partisipan dalam penelitian ini adalah guru kelompok A RA Raihan Persis 27. Pengumpulan data dilakukan dengan teknik observasi, wawancara dan dokumentasi. Teknik analisis data yaitu dengan cara mereduksi data, menyajikan data dan menarik kesimpulan.

\section{TEMUAN DAN PEMBAHASAN}

Dari hasil observasi dan wawancara serta studi dokumen yang dilakukan selama penelitian, peneliti menemukan bahwa upaya dalam mengebangkan kemandirian anak memang sudah menjadi target sekolah yang merupakan rincian dari visi-misi RA Raihan Persis 27. Target tersebut diturunkan menjadi beberapa program yang dibuat menjadi aturan, yaitu aturan sekolah dan aturan kelas. Aturan sekolah dibangun bersama antara pihak sekolah, anak dan orangtua. Untuk mengembangkan kemandirian anak dikelas, ditanggungjawabkan kepada giru kelas masing-masing. Hasil observasi dari kelompok A1, A2 dan A3 peneliti menemukan bahwa upaya guru dalam mengembangkan kemandirian anak serta aspek yang dikembangkannya adalah sebagai berikut.

Tabel 1

Data Hasil Reduksi Obsevasi Upaya Pengembangan Kemandirian Anak pada Kegiatan Penyambutan Kedatangan Anak dalam Pembelajaran Kelompok A RA Raihan Persis 27

\begin{tabular}{|c|c|c|}
\hline No & Upaya/tindakan & $\begin{array}{c}\text { Aspek } \\
\text { kemandirian }\end{array}$ \\
\hline 1 & $\begin{array}{c}\text { Memberikan } \\
\text { kesempatan kepada } \\
\text { anak untuk } \\
\text { mengucapkan salam } \\
\text { terlebih dahulu } \\
\text { sambil mencium } \\
\text { tangan guru. }\end{array}$ & Percaya diri \\
\hline 2 & $\begin{array}{l}\text { Mempersilahkan } \\
\text { anak untuk } \\
\text { meletakkan tas } \\
\text { dtempatnya. }\end{array}$ & \\
\hline 3 & $\begin{array}{c}\text { Mempersilahkan } \\
\text { anak untuk melepas } \\
\text { sepatu dan } \\
\text { mnyimpanya di rak } \\
\text { sepatu }\end{array}$ & Disiplin \\
\hline
\end{tabular}

Tabel 2

Data Hasil Reduksi Obsevasi Upaya Pengembangan Kemandirian Anak pada Kegiatan Pembukaan Kedatangan Anak dalam Pembelajaran Kelompok A RA Raihan Persis 27

\begin{tabular}{|c|c|c|}
\hline No & Upaya/tindakan & $\begin{array}{c}\text { Aspek } \\
\text { kemandirian }\end{array}$ \\
\hline (1) & (2) & (3) \\
\hline 1 & $\begin{array}{c}\text { Memberikan } \\
\text { kesempatan kepada } \\
\text { anak untuk } \\
\text { mengucapkan salam } \\
\text { terebih dahulu ketika } \\
\text { bertemu dengan } \\
\text { guru. }\end{array}$ & \\
\hline 2 & $\begin{array}{c}\text { Memberikan } \\
\text { kesempatan kepada } \\
\text { anak untuk } \\
\text { membantu } \\
\text { menyiapkan dan } \\
\text { menyajikan alat } \\
\text { makan. }\end{array}$ & Pandai bergau \\
\hline 3 & $\begin{array}{l}\text { Mendorong anak } \\
\text { untuk membereskan } \\
\text { alatr makan ke dapu } \\
\text { secara gotong } \\
\text { royong }\end{array}$ & \\
\hline
\end{tabular}




\begin{tabular}{|c|c|c|}
\hline 4 & $\begin{array}{c}\text { Memberikan } \\
\text { kesempatan kepada } \\
\text { anak untuk } \\
\text { mengambil dan } \\
\text { memakai alas kaki } \\
\text { sendiri. }\end{array}$ & \\
\hline 5 & $\begin{array}{c}\text { Memberikan } \\
\text { kesempatan kepada } \\
\text { anak untuk me alat } \\
\text { makan sendiri. }\end{array}$ & \\
\hline 6 & $\begin{array}{c}\text { Memberikan } \\
\text { kesempatan kepada } \\
\text { anak untuk } \\
\text { menuangkan madu } \\
\text { keatas sendok } \\
\text { sendiri. }\end{array}$ & \\
\hline 7 & $\begin{array}{c}\text { Memberikan } \\
\text { kesempatan kepada } \\
\text { anak untuk } \\
\text { meminum madu } \\
\text { sendiri. }\end{array}$ & Percaya Diri \\
\hline 8 & $\begin{array}{c}\text { Memberikan } \\
\text { kesempatan kepada } \\
\text { anak untuk } \\
\text { menyimpan kembali } \\
\text { sendok yang telah } \\
\text { digunakan untuk } \\
\text { meminum madu. }\end{array}$ & \\
\hline 9 & $\begin{array}{c}\text { Memberikan } \\
\text { kesempatan kepada } \\
\text { anak untuk } \\
\text { menuangkan sendiri } \\
\text { air kedalam gelas }\end{array}$ & \\
\hline 10 & $\begin{array}{c}\text { Memberikan } \\
\text { kesempatan kepada } \\
\text { anak untuk } \\
\text { mengambil makanan } \\
\text { sendiri. }\end{array}$ & \\
\hline
\end{tabular}

Lanjutan tabel 2

\begin{tabular}{|ccc|}
\hline (1) & (2) & (3) \\
\hline 11 & Menginformasikan & \\
& kepada anak untuk & \\
& dapat & Tanggungjawab \\
& menyelesaikan & \\
& gambarnya. & \\
\hline
\end{tabular}

\begin{tabular}{|c|c|c|}
\hline 12 & $\begin{array}{c}\text { Menginformasikan } \\
\text { kepada anak untuk } \\
\text { mengikuti kegiatan } \\
\text { membaca do'a-do'a } \\
\text { harian, hafalan } \\
\text { surat-surat dan } \\
\text { bacaan shalat } \\
\text { pendek sampai } \\
\text { selesai. }\end{array}$ & \\
\hline 13 & $\begin{array}{c}\text { Mengintruksikan } \\
\text { anak untuk } \\
\text { membaca iqra }\end{array}$ & \\
\hline 14 & $\begin{array}{c}\text { Memberikan } \\
\text { kesempatan kepada } \\
\text { anak untuk } \\
\text { membereskan alat } \\
\text { makan sendiri. }\end{array}$ & \\
\hline 15 & $\begin{array}{c}\text { Memberikan } \\
\text { kesempatan kepada } \\
\text { anak untuk } \\
\text { mencuci alat makan } \\
\text { sendiri.. }\end{array}$ & \\
\hline 16 & $\begin{array}{c}\text { Memberikan } \\
\text { kesempatan kepada } \\
\text { anak untuk } \\
\text { menyimpan alat } \\
\text { makan yang telah } \\
\text { digunakan ke } \\
\text { dapur. }\end{array}$ & \\
\hline 17 & $\begin{array}{c}\text { Mengajak dan } \\
\text { memberikan contoh } \\
\text { kepada anak untuk } \\
\text { melakukan } \\
\text { beberapa gerakan } \\
\text { pemanasan saat } \\
\text { bermain motorik } \\
\text { kasar. }\end{array}$ & \multirow{4}{*}{ Disiplin } \\
\hline 18 & $\begin{array}{c}\text { Membimbing anak } \\
\text { membaca doa } \\
\text { masuk kamar } \\
\text { mandi untuk } \\
\text { melakukan cuci } \\
\text { tangan }\end{array}$ & \\
\hline 19 & $\begin{array}{l}\text { Memastikan anak } \\
\text { sudah mencuci } \\
\text { tangannya sendiri } \\
\text { sebelum makan }\end{array}$ & \\
\hline 20 & $\begin{array}{l}\text { Memastikan anak } \\
\text { sudah melap }\end{array}$ & \\
\hline
\end{tabular}




\begin{tabular}{|c|c|c|}
\hline & $\begin{array}{l}\text { tangannya sendiri } \\
\text { setelah mencuci } \\
\text { tangan }\end{array}$ & \\
\hline 21 & $\begin{array}{l}\text { Membimbing anak } \\
\text { membaca do'a } \\
\text { keluar dari kamar } \\
\text { mandi dan do'a } \\
\text { masuk ruangan. }\end{array}$ & \\
\hline 22 & $\begin{array}{c}\text { Membimbing anak } \\
\text { membaca do'a } \\
\text { sebelum makan. }\end{array}$ & \\
\hline 23 & $\begin{array}{l}\text { Menginformasikan } \\
\text { anak untuk berjalan } \\
\text { mengantri masuk } \\
\text { kedalam kelas }\end{array}$ & \multirow{4}{*}{$\begin{array}{c}\text { Mengendalikan } \\
\text { emosi }\end{array}$} \\
\hline 24 & $\begin{array}{c}\text { Mengintruksikan } \\
\text { untuk berjalan } \\
\text { mengantri saat } \\
\text { keluar kelas }\end{array}$ & \\
\hline 26 & $\begin{array}{c}\text { Mengabsen } \\
\text { beberapa anak } \\
\text { untuk mencuci } \\
\text { tangan secara } \\
\text { bergiliran }\end{array}$ & \\
\hline 27 & $\begin{array}{c}\text { Mengetafetkan alat } \\
\text { makan }\end{array}$ & \\
\hline
\end{tabular}

Table 3

Data Hasil Reduksi Obsevasi Upaya Pengembangan Kemandirian Anak pada Kegiatan Inti (Pijakan Sebelum Main)

Kedatangan Anak dalam Pembelajaran

Kelompok A RA Raihan Persis 27

\begin{tabular}{|ccc|}
\hline No & Upaya/tindakan & $\begin{array}{c}\text { Aspek } \\
\text { kemandirian }\end{array}$ \\
\hline $\mathbf{( 1 )}$ & $\mathbf{( 2 )}$ & $\mathbf{( 3 )}$ \\
\hline 1 & $\begin{array}{c}\text { Bertanya kepada } \\
\text { anak tentang hal } \\
\text { yang dilakukan } \\
\text { kemarin }\end{array}$ & \\
& Percaya diri \\
\hline 2 & Mempersilahkan & \\
\hline
\end{tabular}

\begin{tabular}{|c|c|c|}
\hline & $\begin{array}{c}\text { anak mengamati, } \\
\text { bertanya tentang } \\
\text { tema tema yang } \\
\text { dikenalkan. }\end{array}$ & \\
\hline 3 & $\begin{array}{c}\text { Mengembangkan } \\
\text { kosa kata anak dan } \\
\text { menanyakan kosa } \\
\text { kata dan } \\
\text { menanyakan } \\
\text { pendapat anak } \\
\text { tentang arti kata yang } \\
\text { dimaksud }\end{array}$ & \\
\hline 4 & $\begin{array}{c}\text { Memberikan } \\
\text { kesempatan kepada } \\
\text { anak untuk memilih } \\
\text { teman untuk bermain }\end{array}$ & \\
\hline 5 & $\begin{array}{c}\text { Memberikan } \\
\text { kesempatan kepada } \\
\text { anak untuk memilih } \\
\text { ragam main }\end{array}$ & \\
\hline 6 & $\begin{array}{l}\text { Menginformasikan } \\
\text { kepada anak untuk } \\
\text { memperlihatkan hasil } \\
\text { karyanya kepada } \\
\text { guru }\end{array}$ & \\
\hline 7 & $\begin{array}{c}\text { Membangun aturan } \\
\text { main bersama anak } \\
\text { (diskusi) }\end{array}$ & $\begin{array}{l}\text { Pandai } \\
\text { bergaul }\end{array}$ \\
\hline 8 & $\begin{array}{c}\text { Membimbing anak } \\
\text { dengan kelompoknya } \\
\text { mendiskusikan ide } \\
\text { bermain yang akan } \\
\text { dibuat anak dengan } \\
\text { alat dan bahan yang } \\
\text { tersedia. }\end{array}$ & \\
\hline
\end{tabular}

Tabel 4

Data Hasil Reduksi Obsevasi Upaya Pengembangan Kemandirian Anak pada

Kegiatan Inti (Pijakan Saat Main)

Kedatangan Anak dalam Pembelajaran

Kelompok A RA Raihan Persis 27

\begin{tabular}{|ccc|}
\hline No & Upaya/tindakan & $\begin{array}{c}\text { Aspek } \\
\text { kemandirian }\end{array}$ \\
\hline$(1)$ & $(2)$ & $(3)$ \\
\hline
\end{tabular}




\begin{tabular}{|c|c|c|}
\hline 1 & $\begin{array}{l}\text { Mendorong anak } \\
\text { untuk bermain } \\
\text { dalam kelompok } \\
\text { kecil }\end{array}$ & \\
\hline 2 & $\begin{array}{l}\text { Mendukung anak } \\
\text { untuk saling } \\
\text { berbagi alat main } \\
\text { dan memainkan } \\
\text { ragam main secara } \\
\text { bergiliran }\end{array}$ & Pandai bergaul \\
\hline 3 & $\begin{array}{c}\text { Memberi } \\
\text { kesempatan kepada } \\
\text { anak untuk } \\
\text { membuat karya } \\
\text { dengan idenya } \\
\text { sendiri }\end{array}$ & \multirow[b]{2}{*}{ Percaya diri } \\
\hline 4 & $\begin{array}{c}\text { Memberi } \\
\text { kesempatan kepada } \\
\text { anak untuk } \\
\text { mencoba alat dan } \\
\text { ragam main } \\
\text { dengan caranya } \\
\text { sendiri }\end{array}$ & \\
\hline 5 & $\begin{array}{c}\text { Memberikan } \\
\text { kesempatan kepada } \\
\text { anak untuk } \\
\text { mengemukakan } \\
\text { gagasannya } \\
\text { melalui alat dan } \\
\text { bahan yang } \\
\text { digunakannya. }\end{array}$ & \\
\hline 6 & $\begin{array}{l}\text { Mendukung anak } \\
\text { untuk bermain } \\
\text { sampai tuntas }\end{array}$ & \multirow[t]{2}{*}{ Tanggungjawab } \\
\hline 7 & $\begin{array}{l}\text { Mengajak anak } \\
\text { untuk } \\
\text { membereskan alat } \\
\text { main sesuai tempat } \\
\text { dan jenisnya. }\end{array}$ & \\
\hline
\end{tabular}

Tabel 5

Data Hasil Reduksi Obsevasi Upaya

Pengembangan Kemandirian Anak pada

Kegiatan Inti (Pijakan Setelah Main)

Kedatangan Anak dalam Pembelajaran

Kelompok A RA Raihan Persis 27

\begin{tabular}{|c|c|c|}
\hline No & Upaya/tindakan & $\begin{array}{c}\text { Aspek } \\
\text { kemandirian }\end{array}$ \\
\hline 1 & $\begin{array}{lr}\text { Mengajak } & \text { anak } \\
\text { untuk } & \text { duduk } \\
\text { melingkar } & \text { dan } \\
\text { menanyakan } & \\
\text { perasaan } & \text { setelah } \\
\text { bermain } & \\
\end{array}$ & \\
\hline 2 & $\begin{array}{l}\text { Menanyakan } \\
\text { kegiatan bermain } \\
\text { yang sudah } \\
\text { dilakukan anak }\end{array}$ & Percaya diri \\
\hline 3 & $\begin{array}{l}\text { Memberikan } \\
\text { kesempatan kepada } \\
\text { anak untuk } \\
\text { menceritakan } \\
\text { kegiatan yang sudah } \\
\text { dilakukan }\end{array}$ & \\
\hline
\end{tabular}

Tabel 6

Data Hasil Reduksi Obsevasi Upaya Pengembangan Kemandirian Anak pada Kegiatan Penutup Kedatangan Anak dalam Pembelajaran Kelompok A RA Raihan Persis 27

\begin{tabular}{|ccc|}
\hline No & Upaya/tindakan & $\begin{array}{c}\text { Aspek } \\
\text { kemandirian }\end{array}$ \\
\hline $\mathbf{( 1 )}$ & (2) & (3) \\
\hline 1 & Membimbing anak \\
& $\begin{array}{c}\text { untuk membaca do'a } \\
\text { masuk kamar mandi } \\
\text { dan do'a keluar }\end{array}$ & \\
& Menginformasikan & Disiplin \\
& kepada anak untuk \\
& berjalan mengantri \\
& keluar ruangan & \\
\hline 3 & Memberikan \\
& kesempatan kepada \\
& anak untuk \\
& mengambil sendiri \\
& alas kaki \\
\hline 4 & Memberikan \\
& kesempatan kepada \\
& anak untuk \\
\hline
\end{tabular}




\begin{tabular}{|c|c|c|}
\hline & $\begin{array}{l}\text { menggunakan alas } \\
\text { kaki sendiri }\end{array}$ & \\
\hline 5 & $\begin{array}{l}\text { Menginformasikan } \\
\text { anak untuk duduk } \\
\text { tertib dikursi masing- } \\
\text { masing }\end{array}$ & \\
\hline 6 & $\begin{array}{l}\text { Menginformasikan } \\
\text { kepada anak } \\
\text { perempuan untuk } \\
\text { menyimpan } \\
\text { kerudung pada } \\
\text { tempatnya sebelum } \\
\text { wudhu dan } \\
\text { menggosok gigi }\end{array}$ & \\
\hline 7 & $\begin{array}{l}\text { Menginformasikan } \\
\text { anak untuk } \\
\text { menggunakan alat } \\
\text { shalat sendiri }\end{array}$ & \\
\hline 8 & $\begin{array}{l}\text { Membimbing anak } \\
\text { untuk berdzikir } \\
\text { setelah melakukan } \\
\text { shalat }\end{array}$ & \\
\hline 9 & $\begin{array}{l}\text { Mnginformasikan } \\
\text { kepada anak untuk } \\
\text { melipat dan } \\
\text { menyimpan alat } \\
\text { shalat pada } \\
\text { tempatnya }\end{array}$ & \\
\hline 10 & $\begin{array}{l}\text { Menginformasikan } \\
\text { kepada anak untuk } \\
\text { mengambil sendiri } \\
\text { alat makan yang } \\
\text { akan digunakan }\end{array}$ & \multirow{4}{*}{ Percaya Diri } \\
\hline 11 & $\begin{array}{c}\text { Memberikan } \\
\text { kesempatan kepada } \\
\text { anak untuk } \\
\text { menuangkan sendiri } \\
\text { air kedalam gelas }\end{array}$ & \\
\hline 12 & $\begin{array}{c}\text { Memberikan } \\
\text { kesempatan kepada } \\
\text { anak untuk } \\
\text { mengambil sendiri } \\
\text { nasi dan lauk- } \\
\text { pauknya }\end{array}$ & \\
\hline 13 & $\begin{array}{c}\text { Memberikan } \\
\text { kesempatan kepada } \\
\text { salah satu anak untuk } \\
\text { dapat memimpin } \\
\text { membacakan do'a }\end{array}$ & \\
\hline
\end{tabular}

\begin{tabular}{|cc|}
\hline \multicolumn{1}{|c|}{ sebelum makan } \\
\hline $14 \quad$ Memberikan \\
& kesempatan kepada \\
& anak untuk \\
& membawa sikat gigi \\
& sendiri \\
\hline 15 & Memberikan \\
& kesempatan kepada \\
& anak untuk \\
& menggosok gigi dan \\
berwudhu tanpa \\
dibantu
\end{tabular}

\begin{tabular}{|c|c|c|}
\hline (1) & (2) & (3) \\
\hline 16 & $\begin{array}{c}\text { Memberikan } \\
\text { kesempatan kepada } \\
\text { anak perempuan } \\
\text { untuk mengambil } \\
\text { sendiri kerudung }\end{array}$ & \\
\hline 17 & $\begin{array}{c}\text { Memberikan } \\
\text { kesempatan kepada } \\
\text { anak untuk melap } \\
\text { sendiri wajahnya } \\
\text { setelah wudhu }\end{array}$ & \\
\hline 18 & $\begin{array}{c}\text { Memberikan } \\
\text { kesempatan kepada } \\
\text { salah satu anak } \\
\text { untuk qamat }\end{array}$ & \\
\hline 20 & $\begin{array}{c}\text { Menginformasikan } \\
\text { kepada anak untuk } \\
\text { mengambil } \\
\text { makanan } \\
\text { secukupnya dan } \\
\text { tidak } \\
\text { menyisakannya }\end{array}$ & \\
\hline 21 & $\begin{array}{c}\text { Menginforsikan } \\
\text { kepada anak untuk } \\
\text { menyimpan sikat } \\
\text { gigi pada } \\
\text { tempatnya }\end{array}$ & Tanggungjawab \\
\hline 22 & $\begin{array}{l}\text { Menginformasikan } \\
\text { kepada anak untuk } \\
\text { menyimpan } \\
\text { kembali alat shalat } \\
\text { yang telah } \\
\text { digunakan }\end{array}$ & \\
\hline 23 & $\begin{array}{c}\text { Mengabsen } \\
\text { beberapa anak }\end{array}$ & $\begin{array}{c}\text { Mengendalikan } \\
\text { Emosi }\end{array}$ \\
\hline
\end{tabular}




\begin{tabular}{|cc|}
\hline \multirow{4}{*}{$\begin{array}{c}\text { untuk bergerak } \\
\text { mencuci tangan } \\
\text { secara bergiliran }\end{array}$} \\
\hline $24 \quad$ Mengabsen \\
beberapa anak \\
untuk bergerak \\
pulang sexara \\
berurutan \\
\hline
\end{tabular}

Tabel 7

Data Hasil Reduksi Obsevasi Upaya

Pengembangan Kemandirian Anak pada

Kegiatan Penutup Kepulangan Anak dalam

Pembelajaran Kelompok A

RA Raihan Persis 27

\begin{tabular}{|c|c|c|}
\hline No & Upaya/tindakan & $\begin{array}{c}\text { Aspek } \\
\text { kemandirian }\end{array}$ \\
\hline 1 & $\begin{array}{c}\text { Memberikan } \\
\text { kesempatan kepada } \\
\text { anak untuk memakai } \\
\text { kaos kaki sendiri }\end{array}$ & \\
\hline 2 & $\begin{array}{c}\text { Memberikan } \\
\text { kesempatan kepada } \\
\text { anak untuk memakai } \\
\text { alas kaki sendiri }\end{array}$ & Percaya diri \\
\hline 3 & $\begin{array}{c}\text { Memberikan } \\
\text { kesempatan kepada } \\
\text { anak untuk memakai } \\
\text { tas sendiri }\end{array}$ & \\
\hline
\end{tabular}

Kemandirian anak dapat diukur melalui indikator-indikator yang dikemukakan oleh para ahli. Indikator-indikator tersebut yang kemudian menjadi acuan para pendidik untuk dapat mengembangkan kemandirian peserta didiknya. Ada beberapa indikator yang telah kemukakan oleh Breer (dalam Lina, 2015, hlm. 3) bahwa ada tujuh indikator kemandirian, yaitu kemampuan fisik, percaya diri, bertanggung jawab, disiplin, pandai bergaul, mau berbagi dan mengendalikan emosi. Sesuai dengan yang diterapkan di RA Raihan bahwa dalam mengembangkan kemandirian anak, guru mencoba mengembangkan semua indikator tersebut baik secara tersirat maupun secara tersurat. Upaya yang dilakukan guru dalam mengembangkan kemandirian anak, yaitu melalui tindakan dan pernyataan. Selain itu juga guru dituntut untuk selalu menjadi model bagi anak selama proses pembelajarn supaya anak dapat meneladani guru, kemudian guru juga melakukan aktivitas rutin atau pembiasaan yang diberikan kepada anak disekolah yang bertujuan untuk melatih kemandirian anak.

Dalam mengembangkan kepercayaan diri anak guru dominan memberikan upaya dengan tindakan. Guru mengembangkan sikap percaya diri anak melalui tindakan, yaitu dengan memberikan kesempatan kepada anak untuk memenuhi setiap kebutuhannya sendiri, misal memberikan kesempatan kepada anak untuk memakai alas kaki sendiri, memberikan kesempatan kepada anak untuk mengambil alat makan sendiri, dan lain sebagainya. Sedangkan pengembangkan kemandirian dalam bentuk pernyataan adalah pernyataan-pernyataan yang berbentuk intruksi atau informasi, misal guru meminta anak untuk menceritakan tentang aktivitas bermain yang sudah dilakukannya disentra bermain saat kegiatan recalling, atau pada pijakan saat main dan jurnal pagi guru biasanya menginformasikan kepada untuk memperlihatkan hasil karyanya. Di Filipina ada sekolah PAUD yang diberi nama TK Pagsasarili, yang berarti "membantu diri menjadi mandiri". Disekolah ini pendidik memberikan hak kesempatan kepada anak untuk dapat belajar, berpikir dan bekerja secara mandiri. Hasil dari didikan tersebut sangat menakjubkan, karena rasa percaya diri anak lulusan TK tersbut sama dengan kemampuan akademik yang dimiliki oleh anak usia kelas tiga SD. yang lebih pnting adalah kemampuan mereka dalam menunjukkan kecintaan dalam bekerja, berdisiplin, berkonstrasi, dan bergembira. Hal ini dapat menjadi bukti bahwa kemandirian anak sangatlah penting untuk dikembangkan supaya anak dapat tumbuh menjadi pribadi yang berprestasi, bukan hanya secara akademik, tetapi berprestasi secara afektif juga. (widayanti. 2015. Hlm 88)

Dalam mengembangkan sikap kemampuan fisik guru memberikan kesempatan kepada anak untuk dapat melakukan aktivitas makan sendiri tanpa dibantu atau dengan sedikit bantuan apabila memang anak membutuhkan bantuan. Selain itu anak diajarkan untuk dapat 
mencuci tangan sendiri atau mengembalikan alat main pada tempanya.

Upaya guru dalam mengembangkan sikap tanggungjawab anak terlihat dari cara guru mengungkapkan pernyataan dan memberikan tindakan. Tindakan dan pernyataan guru yang dilakukan guru untuk melatih sikap tanggungjawab anak, yaitu dengan cara memberikan kesempatan kepada anak untuk dapat menyelesaikan tugas-tugasnya, membereskan alat main yang telah digunakan, mengabiskan makanan yang telah diambilnya saat makan, dan lain sebagainya.

Upaya guru dalam mengembangkan sikap disiplin anak guru dominan memberikan pernyataan dibanding tindakan. Seperti saat guru menyampaikan peraturan permaina, prosedur kerja dan peraturan lainnya. Hal ini bertujuan agar anak dapat menjadi sosok yang memiliki sikap disiplin.

Sikap pandai bergaul, mau berbagi dan mengemdalikan emosi ini saling berkaitan satu sama lain, karena ketiganya adalah sikap yang erat hubungannya dengan orang lain. Anak yang dapat mengendalikan emosi dan suka berbagi pasti akan menjadikannya seorang anak yang pandai bergaul. Upaya guru dalam mengembangkan aspek ini cenderung tersirat, seperti mengintruksikan anak untuk dapat bermain kelompok, mau bermain bergiliran dan lain sebagainya.

\section{SIMPULAN}

Berdasarkan hasil temuan dan pembahasan dapat disimpulkan bahwa upaya pengembangan kemandirian anak sebagai peserta didik dilakukan secara terprogram oleh RA Raihan Persis 27. Anak yang mandiri merupakan salah satu tujuan dan target dari sekolah. Untuk mencapai hal itu sekolah menerapkan beberapa program sebagai bentuk upaya mengembangkan kemandirian anak. Program tersebut dibuat menjadi aturan, yaitu aturan untuk anak, guru dan orangtua. Aturan tersebut dibagi menjadi dua, yaitu aturan sekolah dan aturan didalam kelas. Aturan sekolah berupa tata tertib yang harus dilakukan anak dan orangtua serta bekerjasama dengan guru. Aturan dikelas merupakan aturan yang harus dilakukanoleh anak berupa prosedur kerja dan prosedur main. Aturan ini dimaksudkan untuk mengembangkan kemandirian anak. Pada kelompok A peneliti menyimpulkan bahwa upaya guru dalam mengembangkan kemandirian anak adalah melalui pembiasaan dalam bentuk pernyataan dan tindakan. Sedangkan aspek kemandirian yang dikembangkan oleh adalah aspek pandai bergaul, percaya diri, disiplin, tanggungjawab dan mengendalikan emosi.

\section{SARAN}

Adapun saran dari penelitian ini dittujukan pada :

1. Sekolah sebagai pengelola pendidikan formal yang memberikan pendidikan sebagai pondasi karakter anak untuk membangun anak yang mandiri.

2. Guru dan orangtua sebagai pelaksana pendidikan disekolah dan dirumah agar mampu bekerjasama dengan sekolah dalam membangun karakter mandiri anak.

3. Peneliti selanjutnya sebagai pengembang penelitian terdahulu agar lebih fokus meneliti salah satu aspek kemandirian supaya mendapatkan informasi yang lebih mendetail.

\section{DAFTAR PUSTAKA}

Bukhari, I. B. I, (2014). Mengajarkan Kemandirian Kepada Anak. .Bandung. Khazanah intelektual

Desminta.

(2012). Psikologi

Perkembangan Peserta Didik.

Bandung. PT Remaja Rosdakarya.

Hamdani. (2010). Strategi Belajar

Mengajar. Bandung. CV Pustaka Setia.

Komala. (2015). Mengenal dan mengembangkan kemandirian anak usia dini melalui pola asuh orangtua, 1 (1), hlm 31-45. 
Latif, dkk. (2014). Pendidikan Anak Usia

Dini. Jakarta. Prenadamedia Group.

Lina, E. R.A. (2015). peningkatan kemandirian anak disekolah melalui metode bermain peran di kelompok B TK PKK prawirotaman yogyakarta, 2 (10), hlm. 2.

Marti. (2015). Profil kemandirian anak kelompok B TK 1-ikhlas. (skripsi). FIP, Universitas Pendidikan Indonesia, Bandung.

Putra, K.D dan Jannah, M. (2013). perkembangan kemadiriana anak usia dini 4- tahun di taman kanakkanak Asssalam Surabaya. 3 (1).

Rantika, M. (2015). peningkatan kemandirian melalui kegiatan pembelajaran practical life. 2 (9), hlm. 181-200

Sujiono, Y.N. (2013). Konsep Dasar Pendidikan Anak Usia Dini. Jakarta. PT Indeks 